Egyptian Journal of Aquatic Biology \& Fisheries

Zoology Department, Faculty of Science,

Ain Shams University, Cairo, Egypt.

ISSN $1110-6131$

Vol. 24(5): $289-306$ (2020)

www.ejabf.journals.ekb.eg

\title{
Comparative morphological and histological studies on the adaptation of esophagus and stomach to the feeding habits in some coral reef fishes at Hurghada, Red Sea, Egypt
}

\author{
Walaa Shalaby \\ 1. Zoology Department, Faculty of Science (girls), Al-Azhar University, Cairo, Egypt \\ WalaaShalaby.5920@azhar.edu.eg; Walaa_Tantawy@yahoo.com
}

\begin{tabular}{l} 
ARTICLE INFO \\
Article History: \\
Received: June 13, 202 \\
Accepted: July 25, 202 \\
Online: July 28, 2022 \\
\hline Keywords: \\
Coral reefs, \\
Fish, \\
Comparative study, \\
Esophagus, \\
Stomach, \\
Feeding, \\
Gastric glands
\end{tabular}

\section{ABSTRACT}

The present study deals with the morphological and histological adaptations of the esophagus and stomach of some coral reef fishes (Parupeneus forsskali, Popilloculiceps longiceps and Acanthurus sohal) and their feeding habits. Results showed that the esophagus of carnivorous fish, Parupeneus forsskali, piscivores fish, Popilloculiceps longiceps and herbivores fish, Acanthurus sohal is a short, narrow and distensible muscular tube to conduct the food. Owing to the esophageal mucosa of the three fishes is of a stratified type. The great distensibility of the esophagus is an adaptation for feeding. So a relatively large object can be swallowed. In the $P$. forsskali the mucosa containing large mucus glands. On the other hand in $P$. longiceps and $A$. sohal the mucosa is thrown into primary and secondary folds. The stomach of $P$. forsskali is sac-like in shape. While the stomach of $P$. longiceps is with a great distensibility giving the bag-like shape to enable the fish to take relatively huge prey. The stomachs of these species have a vast amount of gastric glands in the cardiac portion, while, in the pyloric one has a very thick layer of muscularis. The stomach of $A$. sohal is $\mathrm{U}$ shape. It can be divisible into cardiac and pyloric regions. Cardiac region is highly specialized as a masticator organ for the fish that eat hard vegetable matter. The epithelium of the pyloric stomach develops into a thin layer of columnar cells towards the lumen and a thick layer of gastric glands towards the base to help in digestion.

In conclusion, the esophagus and stomach of carnivorous fish, $P$. forsskali, piscivores fish, $P$. longiceps, and herbivores fish, $A$. sohal are subjected to diverse and significant variations and much modification in accordance with the food type and feeding habits.

\section{INTRODUCTION}

Coral reefs are exceptionally biodiverse and productive (Snelgrove, et al., 2016). They are the most species rich marine ecosystem and play a role in the life cycle of one quarter of all marine fish species (Burke, et al., 2008; Knowlton, et al., 2010; Obura, et al., 2019). 
The importance of coral reefs comes from being the second after the rain forests in its biodiversity value. The worldwide reef species ranged from 6 to more than 9 million species (Veron, 2008). The Egyptian coral reefs can be identified as a highly complex ecosystem which provides a home to thousands of species of different flora and fauna in a given area. Coral reefs of the Red Sea support approximately 400 fish species which utilize corals for shelter, food and/or breeding ground (ERSR, 1998; Mohamad, 1999; Bhat, 2004).

The adaptations in reef-dwelling fishes suited to particular kinds of food sources commonly found in coral reef habitats. Feeding types among reef fishes have been classified to four basic types of feeders: herbivores, planktivores, benthic carnivores and piscivores (Randall, 1983; Alevizon, 1994; Lieske and Myers, 1999; Alabssawy, 2019).

Algae are primary producers, which mean they are plants synthesizing food directly from solar energy and carbon dioxide and other simple nutrient molecules. Without algae, everything on the reef would die. One important algal group, the bottom dwelling (benthic) algae, grows over dead coral and other inert surfaces and provides grazing fields for herbivores such as surgeonfish (Acanthurus sohal) (Randall, 1983; De Bruin, et al., 1995; Carpenter, 2002).

Acanthuridae constitutes a family of bony fishes found throughout the tropical and subtropical realm, except the Mediterranean Sea. The family contains about 86 species, of which surgeonfishes (Acanthurinae) are characterized by having sharp scalpel-like spines on caudal peduncles (Nelson, 2006; Eschmeyer, et al., 2017; Froese and Pauly, 2018). The sohal surgeonfish Acanthurus sohal (forsskali, 1775) is a marine species that is native to the Red Sea and the Persian Gulf, where it is considered common. This is a relatively large species (up to $40 \mathrm{~cm}$ TL) that lives mainly on the reef front and is known to be highly territorial and aggressive, causing injuries with its sharp scalpel-like spines at the base of the caudal fin (Froese and Pauly, 2018).

For less competition, the benthic carnivorous can be divided into diurnal and nocturnal feeders for limiting resources occurs among species. The common daylight benthic carnivores that hunt and feed on or near the reef include the goat fish (Parupeneus forsskali) (Azab, et al., 1998; Randall, 1983; Lieske and Myers, 2004). The goatfish of the family Mullidae are marine carnivorous species that are rarely found also in brackish waters. They are important components of the demersal communities across the Atlantic, Indian and Pacific Oceans, and are considered among the most important commercial fish globally (Whitehead, et al. 1986; Nelson, et al. 2016; Pavlov and Emel Yanova, 2018; Evagelopoulos, et al. 2020). Goatfishes are one of the most economically and commercially important groups inhabiting the northern Egyptian Red Sea sector (Sabrah, 2015; Osman, et al., 2020).

The piscivorous coral reef fishes are those that prey mainly or entirely upon other fishes. Corcodylefish are predatory bottom-dwelling fish, using their camouflage to ambush their prey such as Popilloculiceps longiceps. This fish is mottled brown or green and grey, colored ideally to be camouflaged with their habitat and will eat most fish small enough to fit in their mouth. They have eye lappets, which help to break up the outline of the iris and improve camouflage, and can reach a length of $70 \mathrm{~cm}$ (Lieske and Myers, 1999).

The adaptations of the digestive organs of the fish to their normal diet are particularly evident in the form, size, structure, abundance and limitation of the 
microscopically elements such as dentition, mucous cells, taste buds, digestive glands and muscular coat in the esophagus, stomach and intestine in the fish. All of these parameters are subjects to diverse and significant variations and much modification in accordance with the food and feeding habits (Al-Hussini, 1947; Dasgupta, 2000; Khalaf- Allah, 2013; Shalaby, 2017).

The present study aimed to provide comparative description on the morphological and histological adaptations of the esophagus and stomach in some coral reef fishes [goatfish (Parupeneus forsskali), corcodylefish (Popilloculiceps longiceps) and surgeonfish (Acanthurus sohal)] at Hurghada, Red Sea, Egypt according to its feeding habits for understanding the related functional mechanisms of fish digestive physiology and feeding strategy.

\section{MATERIALS AND METHODS}

\section{Specimens collection:}

A total of 19 specimens; 10 of goatfish (Parupeneus forsskali) (Plate 1, A), 4 of corcodylefish (Popilloculiceps longiceps) (Plate 1, C) and 5 of surgeonfish (Acanthurus sohal) (Plate 1, E) were collected by irregular visits from Hurghada, Red Sea, during the period from January - September, 2017. Long lines net were the main fishing method used to collect the fish. Wherever possible fishes were examined fresh or preserved in $10 \%$ formalin solution for taxonomically identified, as far as possible up to genera according to Randall (1983) and Lieske and Myers (2004) and then the following studies were carried out.

\section{Morphological and histological studies:}

For studying the morphology, the tubular part of the digestive tract (esophagus, stomach and intestine) were isolated carefully from the body cavity and preserved in $70 \%$ ethyl alcohol then photographed and described.

For histological studies, small pieces of intestine were removed from the dissected specimens and immediately fixed in alcoholic Bouin`s fluid for at least 48 hours, dehydrated in ascending concentrations of ethyl alcohol, cleared in xylene and embedded in paraplast wax. Transverse sections were cut at the thickness of 4-6 $\mu \mathrm{m}$, stained with Harris`s haematoxylin and eosin for general structure (Humason, 1979), microscopically examined, then photographed and described.

\section{RESULTS}

\section{Morphology and histology of digestive tube: \\ 1.1. The esophagus: \\ 1.1.1. Parupeneus forsskali:}

In the P. forsskali (Plate 1, A). The esophagus is a short muscular distensible tube (Plate 1, B). The esophageal mucosa is thrown into primary folds with tapering tips. The mucosa is of stratified epithelia. The epithelial mucosa consists of a surface thick layer of large mucus glands and a basal layer of undifferentiated cells. The mucus glands are large, tubular or elongated in shape and intermingled with few squamous epithelial cells. 
These glands tend to be more concentrated on the sides and the bases of the mucosal folds (Plate 2, A\&B).

The submucosa consists of fibrous connective tissue, whose meshes are larger towards the muscularis and smaller towards the mucosa. Fat cells and blood vessels are numerous. Tunica muscularis is relatively thick and composed of only one layer of striated circular muscle fibers arranged in small bundles held together by areolar connective tissue. Serosa consists of simple squamous epithelium (Plate 2, A\&B).

\subsubsection{Popilloculiceps longiceps:}

The esophagus of $P$. longiceps is a short muscular distensible tube (Plate 1, D). The esophageal mucosa is composed of primary and secondary folds. The primary folds are finger in shape with round tips while the secondary ones are short with round or blunt tips. The epithelial mucosa consists of 1- 3 rows of mucus cells. Mucus cells are large in size and highly abundant. They tend to be more concentrated on the sides, crests and the bases of the mucosal folds. Mucus secreting cells are saccular, round or polygonal in shape and combined with few squamous epithelial cells. Serosa consists of simple squamous epithelium (Plate 2, C\&D).

\subsubsection{Acanthurus sohal:}

The esophagus of $A$. sohal is a short muscular distensible tube (Plate 1, F). The basic layers making up the wall are the mucosa, submucosa, muscularris and serosa. The mucosal folds are elongated and branched to many secondary folds on the crests and sides of the folds. These folds made up of stratified epithelium. Such structure is highly abundant at the sides and bases of the mucosal folds which are globular or pyriform in shape. They are combined with few squamous epithelial cells. At the transitional region between the esophagus and the stomach, the epithelium is of the columnar type. The mucosa is of a typical columnar type towards the lumen and gastric glands towards the base (Plate 2E\&F). The submucosa consists of fibrous connective tissue, richly supplied with blood vessels. Muscularis mucosa is well developed. Tunica muscularis is relatively thick layer of one layer, only one circular striated muscle fibers. This layer arranged in small bundles held together by an areolar connective tissue. Serosa consists of pavement epithelium (Plate 2E\&F).

\subsection{The stomach:}

\subsubsection{Parupeneus forsskali:}

The stomach of goatfish, $P$. forsskali is of e sac-like shape and can be divided into cardiac and pyloric regions. The cardiac region is continuous with oesophagus, forming a cone shape. The base of the cone is connected on a lesser curvature to give the pyloric portion. The boundaries between the two regions can be hardly distinguished (Plate 1, B). The wall of each portion is made up of the ordinary four layers: mucosa, submucosa, muscularis and serosa.

\section{Cardiac stomach:}

The mucosa of the cardiac stomach of $P$. forsskali is thrown into large, short and broad primary folds with tapering ends. The epithelial mucosa is made up of two layers: columnar epithelium and a relatively thick layer of tubular gastric glands. The former occupies the luminal side while, the latter occupy the basal side of the mucosal folds. The 
tubular gastric glands form a conspicuous layer beyond the columnar cells (Plate 3C\&D).

The submucosa consists of areolar connective tissue richly supplied with fibrocytes, lymphocytes, blood vessels and large lymph spaces. The muscular coat is comparatively thick and built up of two layers, an outer longitudinal and an inner circular muscle layers; both of which are of unstriated type. The inner layer is much thicker than the outer one. The serosa is made up of simple squamous epithelium (Plate 3C\&D).

\section{Pyloric stomach:}

There is no marked boundary between the pyloric and cardiac stomach. However, some differences may be easily detected. The lumen is widest at the entrance to the cardiac and decreases towards the pyloric orifice. The mucosa is thrown into thin reticular folds. The former is made up of pseudo-stratified columnar epithelium. Gastric glands and mucus cells are fewer in number (Plate 4C\&D).

The submucosa is relatively thick and made up of areolar connective tissue, whose meshes are occupied mainly by large oval fibrocytes. The muscular coat is relatively thick consists of two layers inner layer and outer one. The inner layer is much thicker than the outer one. The serosa consists of simple squamous epithelium (Plate 4C\&D).

\subsubsection{Popilloculiceps longiceps:}

The stomach wall of corcodylefish, $P$. longiceps is of a great distensibility giving the bag-like shape stomach to enable these fishes to take relatively huge prey. The stomach is divided into the proximal cardiac and the distal pyloric regions. The boundaries between two regions can hardly be distinguished (Plate 1, D). The wall of each portion is made up of the ordinary four layers: mucosa, submucosa, muscularis and serosa.

\section{Cardiac stomach:}

The epithelial mucosa is thrown into primary folds. The latter are long, thick and few in number. They are longitudinal in direction, compact with deep crypts and laying in close contact to each other with round tips (Plate 3A\&B).

The epithelial mucosa is made up of thin layer of simple columnar cells towards the lumen and a thick layer of tubular gastric glands towards the base. In between, many nests of mucus cells are arranged at the origin of columnar cells (Plate 4A).

The submucosa is relatively thin and consists of fibrous connective tissue with fibrocytes, lymphocytes, blood vessels and large lymph spaces. Muscular coat is thick and is built up of two layers, an outer longitudinal and an inner circular unstriated muscle layers. The inner layer is much thicker than the outer one. The latter was arranged in small bundles held together by fibrous connective tissue. The serosa is pavement epithelium (Plate 4A).

\section{Pyloric stomach:}

The histological features of pyloric stomach are similar to that is found in the cardiac stomach, however, some differences can be easily detected. In the pyloric stomach, the primary folds are large in number, irregular in shape with deep crypts and 
round tips. Gastric glands are absent. Mucus cells are numerous. The circular muscle fibers become more thick gradually towards the intestine (Plate 4B).

\subsubsection{Acanthurus sohal:}

The stomach of surgeonfish, $A$. sohal is U shape. It can be divided into cardiac and pyloric regions. Cardiac region is highly specialized as a masticator organ for the fish that eat hard vegetable matter (Plate 1, F).

\section{Cardiac stomach:}

It is characterized by the followings: the tough non-cellular lining, which consists of keratinoid substances and a thick powerful muscular coat. The mucosa is thrown into primary folds, which are few, thick and short, irregular in shape. The columnar cells constitute the more common type in the mucosa; the general form of these cells varies slightly according to their location in the mucous membrane. They are cylindrical in shape and wider at their tops than at their bases. Lamina propria of primary folds is relatively wider and consists of a highly cellular, lymphoreticular tissue richly supplied with granulocytes, fibrocytes, lymphocytes and large blood vessels.

The submucosa is made up of fibrous connective tissue richly supplied with fibrocytes, lymphocytes and large blood vessels. Muscular coat is thick and is built up of two layers of unstriated muscle fibers. An outer longitudinal and an inner circular one. The inner layer is much thicker than the outer one. The serosa is made up of pavement epithelium (Plate 3A\&B).

\section{Pyloric stomach:}

The histological features of pyloric stomach are very similar to that is found in the cardiac stomach, however, some differences can be easily detected. In the pyloric stomach, the primary folds are short, large broad with round tips and give numerous secondary and tertiary folds. The latter are thin, longitudinal in direction, compact with deep crypts and laying in close contact to each other with round tips. Gastric glands are numerous. The muscular coat is very thick. The inner layer is much thicker than the outer one. The serosa consists of simple squamous epithelium covering a thin layer of subserosa (Plate 4C\&D). 


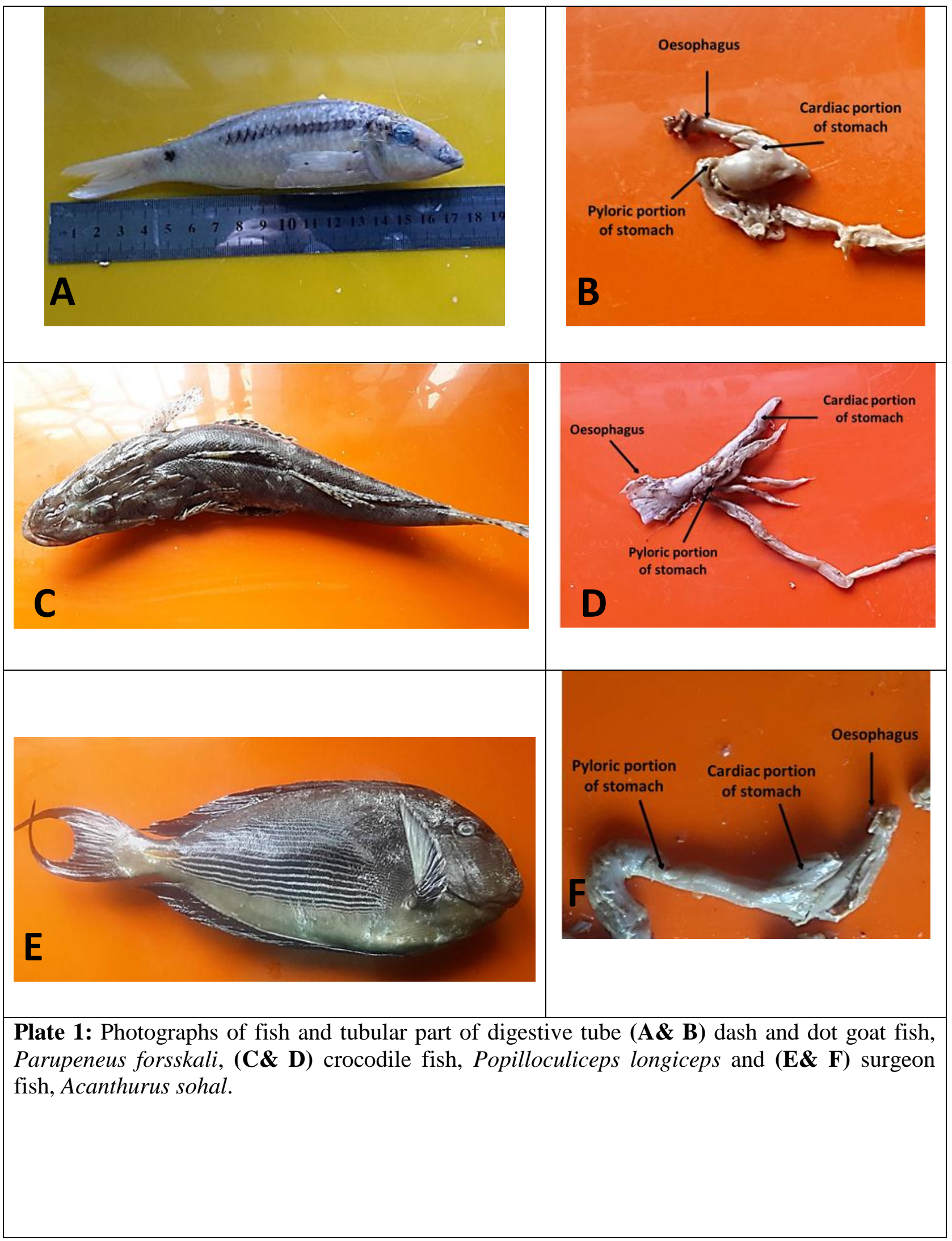




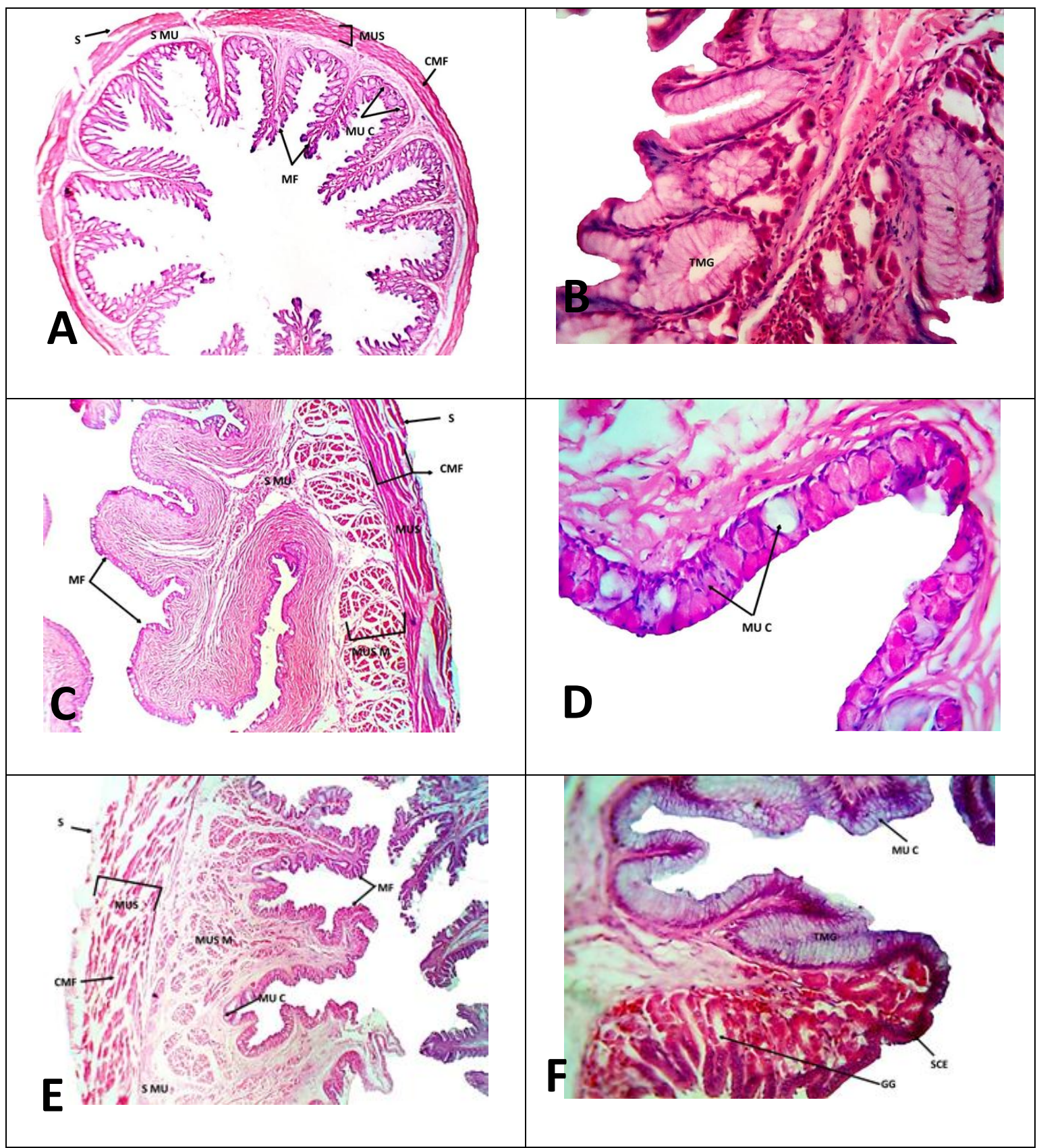

Plate 2: Photomicrographs of T.S. of the oesophagus of: (A\& B) Parupeneus forsskali, (C\& D) Popilloculiceps longiceps and (E\& F) Acanthurus sohal. showing circular muscle fibers (CMF), gastric glands (GG), muscularis (MUS), muscularis mucosa (MUS M ), mucous cells (MU C), mucosal folds (MF), serosa (S), submucosa (SMU), simple columnar epithelium (SCE) and tubular mucous gland (TMG) (A,C \& E Hx \& E x 40 and B,D \& F Hx \& E x 400). 


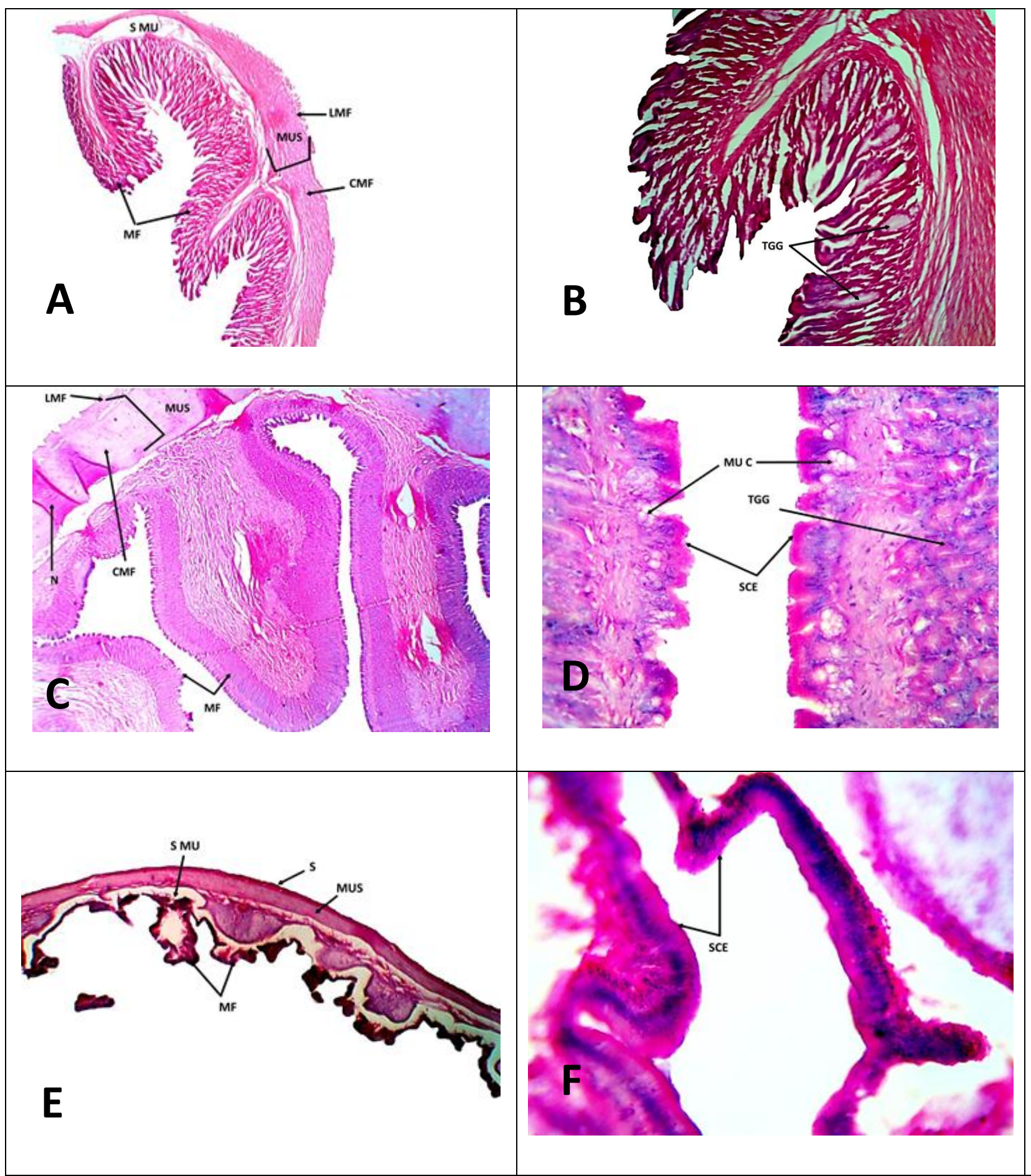

Plate 3: Photomicrographs of T.S. of the cardiac portion of stomach of: (A\& B) Parupeneus forsskali, (C\& D) Popilloculiceps longiceps and (E\& F) Acanthurus sohal showing circular muscle fibers (CMF), longitudinal muscle fibers (LMF), muscularis (MUS), mucous cells (MU C), mucosal folds (MF), nerve (N), serosa (S), submucosa (SMU), simple columnar epithelium (SCE) and tubular gastric glands (TGG) (A,C \& E Hx \& E x 40, B Hx \& E x 100 and D \& F Hx \& $\mathrm{E} \times$ 400). 


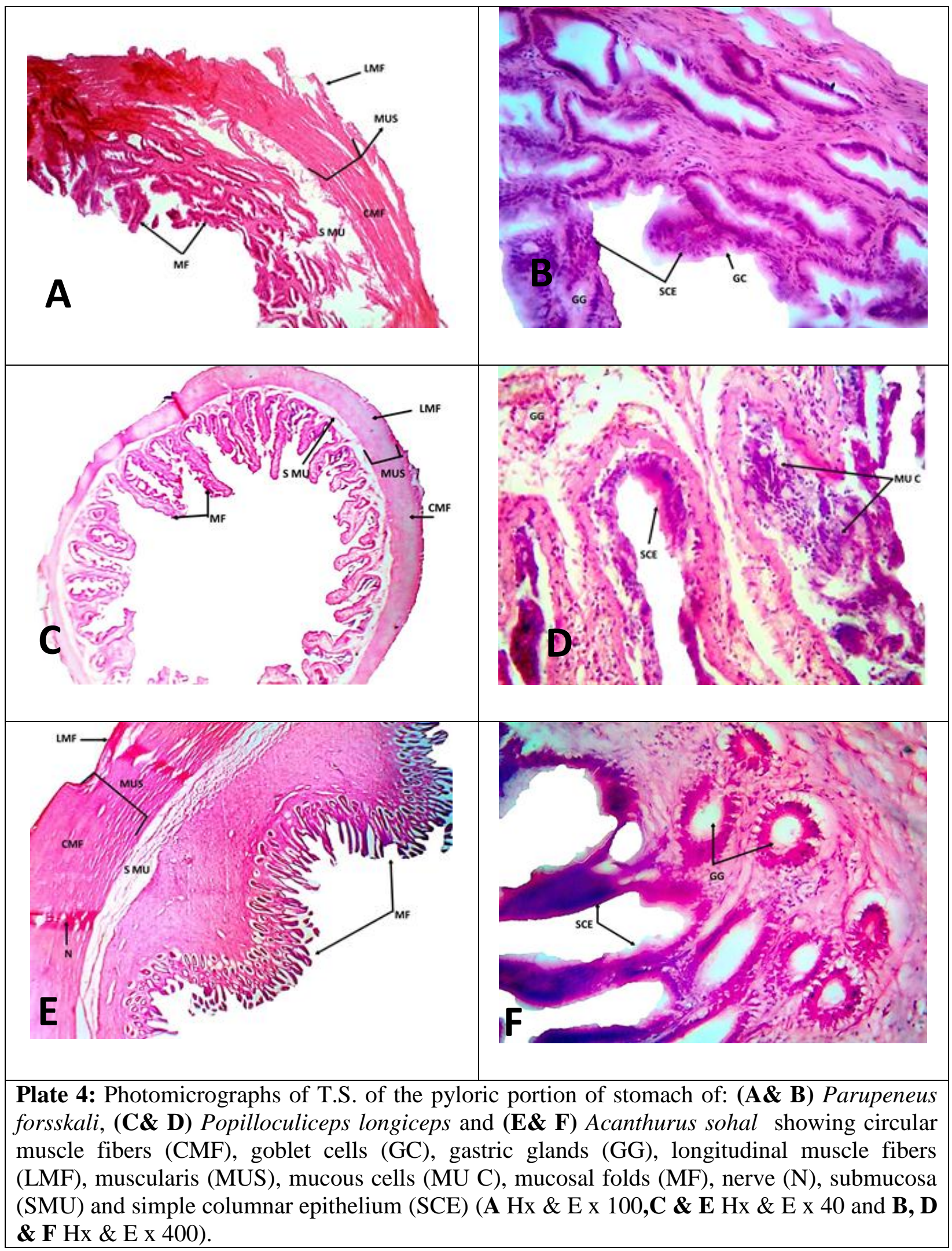




\section{DISCUSSION}

The adaptations of the digestive tract of the fishes to their food are particularly evident in the form of dentitions, esophagus, stomachs, intestine and the gut length (Dasgupta, 2000; Al-Abdulhadi, 2005; Khalaf-Allah, 2013).

In the present study, the esophagus of carnivorous fish, Parupeneus forsskali, piscivores fish, Popilloculiceps longiceps and herbivores fish, Acanthurus sohal are a short, narrow and distensible muscular tube. The great distensibility of the esophagus is due to adaptation for feeding. So a relatively large object can be swallowed. In this respect, the esophagus of these fishes resembles the esophagus of many fishes including Lates niloticus (Albattal, 2002), Clarias gariepinus and Bagrus bajad (Hussein, 2004), Mylio cuvieri and Tilapia spilurus (Al-Abdulhadi, 2005), Terapon puta, Lithognathus mormyrus and Cheilinus lunulatus (Khalaf-Allah, 2009, 2013), Mulloidichthys flavolineatus and Tylosurus choram (Abdel-Wahab, et al., 2017).

In the present work, the esophageal mucosa of carnivorous fish, $P$. forsskali is of a stratified type. The epithelial mucosa consists of a surface thick layer of large mucus glands and a basal layer of undifferentiated cells. The mucus glands are large, highly abundant, tubular or elongated in shape and intermingled with few squamous epithelial cells. In the light of this observation, mucus secreted in the digestive tract is the first protective barrier against mechanical, physical and chemical factors as well as against infections besides the protection of mucosa against acidic secretory products (Azab, et al., 1998; Zaiss, et al., 2006; Yashpal, et al., 2007; Khalil, et al., 2011; Hashem, et al., 2012; Mabrouk, 2015; Shalaby, 2017).

In contrast, some authors mentioned that the conspicuous layer beneath the columnar cells in the esophagus is not tubular mucous glands, but gastric glands. The digestive glands are found in the posterior region of esophagus used in the digestion in the esophagus of Mugil cephalus (Shehata, 1997), Liza aurata, Terapon jarbua (KhalfAllah, 2001, 2012) and Siganus rivulatus (Abdel -Wahab, et al., 2017).

However, the esophageal mucosa of piscivores fish, P. longiceps and herbivores fish, A. sohal are thrown into primary folds and branched to secondary folds to increase distention during food consumption or increase the digestive activities. The muscular coat is very thick and formed of only one circular layer, for facilitating conduction of the food to stomach. The mucosa is of a stratified type. Mucus cells are highly abundant. Therefore, the food can easily pass posteriorly without causing any damage to the epithelial lining of the soft mucosa. In this respect, the esophagus of these fishes are similar in structure to the most fishes described by Abu-Zinadah (1990), Zaki et al. (1994), Shehata (1997), Khalaf-Allah (2001, 2009), Hussein (2004), Kozaric et al. (2008) and Abdel -Wahab et al. (2017).

The stomach is a specialized organ located in the anterior gut in many vertebrates, characterized by the occurrence of acid $(\mathrm{HCl})$ and pepsin-producing gastric glands (Koelz, 1992). The stomach has multiple functions which include storage of food, initiation of protein digestion, inactivation of pathogens and controlling chyme release to the intestine (Wilson and Castro, 2010). The storage function of the stomach allows an animal to ingest larger meals (Castro, et al., 2014; Le, et al., 2019). 
The stomach shows various adaptations according to food and feeding habits. The stomach is specialized for masticating as well as for secretion purpose. (Kumar and Tembhre, 1996).

From the present results, the stomach of carnivorous fish, $P$. forsskali is of the saclike shape. It can be divided into cardiac and pyloric regions. Similar result was recorded on the same species (Azab, et al., 1998), In this respect, the stomach of these fish resembles the stomach of many carnivorous fish including Morone labrax (Shehata, 1997), Lates niloticus (Albattal, 2002), Clarias gariepinus and Bagrus bajad (Hussein, 2004), Mylio cuvieri and Tilapia spilurus (Al-Abdulhadi, 2005), Terapon puta (KhalafAllah, 2009), Epinephelus chlorostigma (Hassan, 2013) and Mulloidichthys flavolineatus (Abdel-Wahab, et al., 2017).

On the other hand, the stomach of piscivorous fish, $P$. longiceps is a great distensibility giving the bag-like shape to enable this fish to take relatively huge prey. This result is disagreement with that obtained by Shalaby (2017). He mentioned that the stomach of piscivorous fish (T. choram) is of the pseudo-gastric or false stomach.

The stomachs in carnivorous fish, $P$. forsskali and piscivorous fish, $P$. longiceps have a vast amount of gastric glands in the cardiac portion, while, in the pyloric one has a very thick layer of muscularis which helps in regulating the passage of the digested food to the intestine (Shehata, 1997; Albattal, 2002; Hussein, 2004; Al-Abdulhadi, 2005; Shalaby, 2017). These revealed that, the mucosa of the stomachs in carnivorous fish, $P$. forsskali and piscivorous fish, $P$. longiceps are of the remarkable thickness, due to the occurrence of enormous numbers of tubular gastric glands. Such structures are highly abundant in the cardiac stomach, and less in the pyloric one. The mucosa is lined with simple columnar epithelium. Muscularis is made up of two layers, an outer longitudinal and an inner circular muscle fibers. Similar observations are described in carnivorous fish by many authors on P. forsskali (Azab, et al., 1998), Lates niloticus (Albattal, 2002), Mylio cuvieri (Al-Abdulhadi, 2005), Terapon puta and Terapon jarbua (Khalaf-Allah, 2009, 2012), Epinephelus chlorostigma (Hassan, 2013) and Mulloidichthys flavolineatus (Abdel -Wahab, et al., 2017).

The present study revealed that the stomach of herbivorous fish, A. sohal is U shape. It can be divided into cardiac and pyloric regions. Cardiac region is highly specialized as a masticator organ for the fish that eat hard vegetable matter. Similar results are obtained in herbivorous fish (Hassan, 1991; Almeida, et al., 1993; Shehata, 1997; Khalaf-Allah, 2001 and Abdel -Wahab, et al., 2017).

Moreover, the cardiac stomach of herbivorous fish, A. sohal is characterized by the tough non-cellular lining and a thick powerful muscle to form mechanical digestion. The epithelium of the pyloric stomach develops into a thin of columnar cells towards the lumen and a thick layer of gastric glands towards the base to form chemical digestion. This result agrees with the previous result on the stomach of herbivorous fish described by Eda et al. (1991), Hassan (1991), Almeida et al. (1993), Shehata (1997), Khalaf-Allah (2001) and Abdel -Wahab et al. (2017).

\section{REFERENCES}

Abdel-Wahab, S.M.M.; El-Deeb, R.M.A.; Khalaf-Allah, H.M.M.; Abu-Zaid, M.M. and Shalaby, W.T.S. (2017). Morphological and histological adaptations in the 
oesophagus and stomach of some coral reef fishes in Hurghada, Red Sea, Egypt in relation to feeding strategy. International Journal of Environmental science and engineering (IJESE)., 8: 1- 14.

Abu- Zinadah, O.A. (1990). Studies on Red Sea fish. Ph.D. Thesis, Zoology Dep., School of Biological Science, University College of Swan Sea.

Al-Abdulhadi, H.A. (2005). Some comparative histological studies on alimentary tract of tilapia fish, Tilapia spilurus and sea bream, Mylio cuvieri. Egypt. J. Aqua. Res., 31 (1): $387-398$.

Alabssawy, A.N.; Khalaf-Allah, H.M.M. and Gafar, A.A. (2019). Anatomical and histological adaptations of digestive tract in relation to food and feeding habits of lizardfish, Synodus variegatus (Lacepède, 1803). Egyptian Journal of Aquatic Research 45 (2019): 159-165.

Albattal, A.A.E. (2002). Biological studies on the reproduction of Lates niloticus. M. Sc. Thesis, Zool. Dep., Fac. Sci., Al-Azhar Univ. Cairo. 294 pp.

Alevizon, W.S. (1994). Pisces Guide to Caribbean Reef Ecology. Gulf Publishing Company. Lonely Planet. 115 pp.

Al-Hussini, A.H. (1947). The feeding habits and the morphology of the alimentary tract of some teleosts living in the neighbour hood of the Marine Biological Station, Ghardaqa, Red Sea. Pub. Mar. Biol. St. Ghard. Red Sea, 5: 1-61.

Almeida, P.R.; Moreira, F.; Costa, J.L.; Assis, C.A. and Costa, M.J. (1993). The feeding strategies of liza ramada in fresh and brackish water in the River Tagus, Portugal. J. Fish Biol., 42: 95 - 107.

Azab, A.M.; El-Deeb, R.M. and Shehata, S.M.A. (1998). Anatomical and histochemical studies on the alimentary tract of two benthic marine fishes of different feeding habits. I- Esophagus and stomach. Egypt. J. Aqua. Biol. Fish., 2 (4): $425-440$.

Bhat, A. (2004). Nature Watch Coral Reefs and their Fauna: An Underwater Fantasyland. Resonance, 9: 62-73.

Burke, L.; Bryant, D.; McManus, J.; and Spalding, M. (2008). Reefs at Risk. World Resources Institute (WRI). $56 \mathrm{pp}$.

Carpenter, K. E. (2002). The living marine resources of the western central Atlantic. Volume 3: Bony fishes part 2 (Opisthognathidae to Molidae), sea turtles and marine mammals. In: FAO Species Identification Guide for Fishery Purposes and American Society of Ichthyologists and Herpetologists. Special Publication $\mathrm{N}^{\circ} 5$, FAO, Rome, Italy, pp. 1375-2127. 
Castro, L. F. C.; Gonçalves, O.; Mazan, S.; Tay, B.-H.; Venkatesh, B. and Wilson, J. M. (2014). Recurrent gene loss correlates with the evolution of stomach phenotypes in gnathostome history. Proc. Biol. Sci. 281:20132669. doi: 10.1098/ rspb.2013.2669

Dasgupta, M. (2000). Adaptation of the alimentary tract to feeding habits in four species of fish of the genus Channa. Indian J. Fish., 47 (3): 265 - 269.

De Bruin, G.H.P.; Russell, B.C. and Bogusch, A. (1995). FAO species identification field-guide for fishery purposes. The marine fishery resources of Sri Lanka. FAO, Rome, Ital. 400 pp.

Eda; Marashige, R.; Oozeki, Y.; Hagiwara, A.; Eastham, B.; Bass, P.; Tamari, C.S. and Lee, C. S. (1991). Factors affecting intestine larvae rearing of striped mullet, Mugil cephalus. Aquaculture, 91: 281-294.

ERSR (1998). Red Sea coastal and marine protected area strategy Egyptian Red Sea coastal marine resource management project funded by the Global environment facility/World Bank Red Sea Governorate, ARE, Report, (Part 2), pp. 1 - 5.

Eschmeyer, W.N.; Fricke, R. and Van der Laan, R. (2017). Catalog of Fishes. California Academy of Sciences, San Francisco. https://researcharchive.calacademy.org/research/ichthyology/catalog/fishcat main.asp (accessed on 13 January 2019)

Evagelopoulos, A.; Nikolaou, A.; Michailidis, N.; Kampouris, T.E. and Batjakas, I.E. (2020). Progress of the dispersal of the alien goatfish Parupeneus forsskali (Fourmanoir \& Guézé, 1976) in the Mediterranean, with preliminary information on its diet composition in Cyprus. BioInvasions Records 9 (2): 209-222. https://doi.org/10.3391/bir.2020.9.2.06

Froese, R. and Pauly, D. (2018). FishBase. www.fishbase.org, version (06/2018)

Hashem, A.M.; Khalil, N.A. and EI-Gohary, N.M. (2012). Effect of rearing temperature on larval growth and the digestive system development in the Nile tilapia, oreochromis niloticus. J. Egypt. Ger. Soc. Zool., 64 (C): 49-76.

Hassan, A.A. (2013). Anatomy and histology of the digestive system of the carnivorous fish, the brown-spotted grouper, Epinephelus chlorostigma (Pisces; Serranidae) from the Red Sea. Life Science Journal, 10 (2): 2149-2164.

Hassan, H.A. (1991). Studies on acclimatization, feeding and growth of some marine fishes (Mugil cephalus L.) in freshwater. M.Sc. Thesis, Fac. Agricul., Alexandria University.

Humason, G.L. (1979). Animal Tissue Techniques. Freeman, W.H. \& Co., San Francisco. 641 pp. 
Hussein, T.D. (2004). Comparative histomorphometric study on the alimentary canal of two bony fish species: Clarias gariepinus and Bagrus bajad. Egypt. J. Zool., 42: 1 -17 .

Khalaf-Allah, H.M.M. (2001). Ecological and biological studies on some fish in Lake Qarun, Egypt. M.Sc. Thesis, Zool. Dep. Fac. Sci., Al-Azhar Univ., Egypt. 331 pp.

Khalaf-Allah, H.M.M. (2009). Biological studies on some Mediterranean Sea fish species with special reference to their feeding habits, growth and reproduction. Ph.D. Thesis, Zool. Dep. Fac. Sci., Al-Azhar Univ., Egypt. 432 pp.

Khalaf-Allah, H.M.M. (2012). Histological and histochemical studies of digestive tract of Terapon fish Terapon jarpua inhabiting Gulf of Aqaba. Al-Azhar bull. Sci. $8^{\text {th }}$ I.S.C., pp.1-16.

Khalaf-Allah, H.M.M. (2013). Morphological adaptations of digestive tract according to food and feeding habits of the broomtail wrasse, Cheilinus lunulatus. Egypt. J. Aquat. Biol. \& Fish., 17 (1): 123-141.

Khalil, N.A.; Khalaf-Allah, H.M.M. and Mousa, M.A. (2011). The effect of maternal thyroxine injection on growth, survival and development of the digestive system of Nile tilapia, Oreochromis niloticus, larvae. Advances in Bioscience and Biotechnology, 2: 320-329.

Knowlton, N.; Brainard, R. E.; Fisher, R.; Moews, M.; Plaisance, L. and Caley, M. J. (2010). "Coral reef biodiversity," in Life in the World's Ocean: Diversity, Distribution, and Abundance, ed A. McIntyre (Wiley-Blackwell), 65-78. doi: 10.1002/9781444325508.ch4.

Koelz, H. R. (1992). Gastric acid in vertebrates. Scand. J. Gastroenterol. 27: 2-6. doi: $10.3109 / 00365529209095998$

Kozaric, Z.; Kuzir, S.; Petrinec, Z.; Gjurcevic, E. and Bozic, M. (2008). The development of the digestive tract in larval European cat fish, Silurus glanis. Anatomia Histologia Embryologia., 37 (2): 141 - 146.

Kumar, S. and Tembhre, M. (1996). Digestive system. In: Anatomy and Physiology of Fish. Kumar, S. and Tembhre, M. (eds.). Kay Kay printers, Delhi, pp. 55 - 75.

Le, H. T. M. D.; Shao, X.; Krogdah, Å.; Kortner, T. M.; Lein, I.; Kousoulaki, K.; Lie, K. K. and Sæle, Ø. (2019). Intestinal Function of the Stomachless Fish, Ballan Wrasse (Labrus bergylta). Front. Mar. Sci. 6:140. doi: 10.3389/fmars. 2019.00140

Lieske, E. and Myers, R. (1999). Collins Pocket Guide. Coral reef fishes. Indo Pacific and Caribbean including the Red Sea. Haper Collins Publishers. London, 400 pp. 
Lieske, E. and Myers, R.F. (2004). Coral Reef Guide, Red Sea. Lieske, E. and Myers, R.F. (eds.). D \& N Publishing, Hungerford, Berkshire, Hong Kong. 365 pp.

Mabrouk, R.T.M. (2015). Effect of environmental factors on larval growth and development of Gilthead seabream (Sparus aurata). M. Sc. Thesis, Zool. Dep., Fac. Sci., Al-Azhar University, Cairo, Egypt,. 236 pp.

Mohamed, A.S. (1999). Population dynamics and stock assessment of some species of genus Cephalopholis and genus Variola from the Red Sea Egypt. M.Sc. Thesis, Zool. Dept., Fac. Sci., Assiut University. 149 pp.

Nelson, J.S. (2006). Fishes of the World (4th Edition). John Wiley \& Sons Inc., New York, $601 \mathrm{pp}$.

Nelson, J.S.; Grande, T.C. and Wilson, M.V.H. (2016). Fishes of the World, 5th Edition. John Wiley \& Sons Inc., Hoboken, USA. 707 pp. https://doi.org/10.1002/9781119174844

Obura, D. O.; Aeby, G.; Amornthammarong, N.; Appeltans, W.; Bax, N.; Bishop, J.; Brainard, R. E.; I Chan, S.; Fletcher, P.; Gordon, T. A. C.; Gramer, L.; Gudka, M.; Halas, J.; Hendee, J.; Hodgson, G.; Huang, D.; Jankulak, M.; Jones A.; Kimura, T.; Levy, J.; Miloslavich, P.; Chou, L.M.; Karger, F. M.; Osuka, K.; Samoilys, M.; Simpson, S. D.; Tun, K.; and Wongbusarakum, S. (2019). Coral Reef Monitoring, Reef Assessment Technologies, and EcosystemBased Management. Front. Mar. Sci. 6:580. doi: 10.3389/fmars.2019.00580.

Osman, A.G.M.; Farrag, M.M.; Mehanna, S.F. and Osman Y.A. (2020). Use of otolithic morphometrics and ultrastructure for comparing between three oatfish species (family: Mullidae) from the northern Red Sea, Hurghada, Egypt. Iranian Journal of Fisheries Sciences 19 (2): 814-832.

DOI: $10.22092 /$ ijfs.2018.120044.

Pavlov, D.A. and Emel Yanova, N.G. (2018). Variation of Freckled Goatfish Upeneus tragula (Mullidae): Color Morphs off Hon Thom (Gulf of Thailand, South China Sea). Journal of Ichthyology, 58 (3): 371-381.

Randall, J.E. (1983). Red Sea Reef Fishes. IMMEL publishing limited, U.K. London. $192 \mathrm{pp}$.

Sabrah, M.M. (2015). Fisheries biology of the Red Sea goatfish Parupeneus forsskali (Fourmanoir \& Guézé, 1976) from the northern Red Sea, Hurghada, Egypt. The Egyptian Journal of Aquatic Research. 41(1): 111-117. 
Shalaby, W.T.S. (2017). Comparative study on the structural adaptation due to feeding strategy in some coral reef fishes. M.Sc. Thesis, Zool. Dep. Fac. Sci., Al-Azhar Univ., Egypt. 241 pp.

Shehata, S.M.A. (1997). Anatomical and histochemical studies on the oesophagus and stomach of certain teleostean fishes with interference to their adaptational features. Al-Azhar Bull. Sci., Vol. 8 (2): 735 - 767.

Snelgrove, P.; Vanden Berghe, E.; Miloslavich, P.; Bailly, N.; Brandt, A. and Bucklin, A. (2016). Global Patterns in Marine Biodiversity. In: The First Global Integrated Marine Assessment - World Ocean Assessment). Chapter 34. (Coordinators) Lorna Inniss and Alan Simcock The Group of Experts of the Regular Process. C. United Nations. Available online at: http://www.un.org/ Depts/los/global_reporting/WOA_RegProcess.htm

Veron, J.E.N. (2008). A Reef in Time: The Great Barrier Reef from Beginning to End. Harvard University Press. $174 \mathrm{pp}$.

Whitehead, P.J.P.; Bauchot, M.L.; Hureau, J.C.; Nielsen, J. and Tortonese, E. (1986). Fishes of the NorthEastern Atlantic and the Mediterranean. Volumes I-III. UNESCO, Paris, France, 1473 pp, https://doi.org/10.2307/1444931

Wilson, J. M. and Castro, L. F. C. (2010). "1 - Morphological diversity of the gastrointestinal tract in fishes," in Fish Physiology, eds A. P. F. Martin Grosell and J. B. Colin (Cambridge, MA: Academic Press), pp. 1-55.

Yashpal, M.; Kumari, U.; Mittal, S. and Mittal, A.K. (2007). Histochemical characterization of glycoproteins in the buccal epithelium of the catfish, Rita rita. Acta Histochem., 109: 285-303.

Zaiss, M.; Papadakis, I.; Divanach, P.; Maingot, E. and Mylonas, C.C. (2006). Ontogeny of the digestive tract in shi drum (Umbrina cirrrosa L.) reared using the mesocosm larval rearing system. Aquaculture, 260: 357-368.

Zaki, Z.T.; Shehata, S.M.A. and Ibrahim, G.I. (1994). Anatomical and histochemical studies of the alimentary tract of some fresh water teleosts. I- Oesophagus and stomach. Proc. Egypt. Acad. Sci., 44: 67 - 80. 


\section{Arabic Summary}

\section{دراسة مقارنة مورفولوجية وهستولوجية لموائمة المرئ و المعدة وارتباطها بالسلوك الغذائى لبعض أسماك

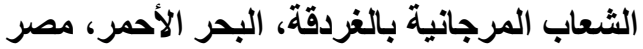

\section{ولاء طنطاوى سلامة شلبى}

قسم علم الحيو ان- كلية العلوم (بنات)- جامعة الأزهر - القاهرة

تتتاول الدراسة الحالية دراسة مقارنة لموائمة التركيب المورفولوجي و الهستولوجي للمرئ و المعدة المئي

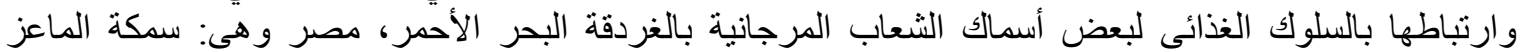
(Parupeneus forsskali) الأسماك وسمكة الجراح (Acanthurus sohal) عشبية التغذية. أظهر الوصف الخارجى أن المرئ فى الأسماك محل الدراسة عبارة عن أنبوبة عضلية قصبرة وضيقة

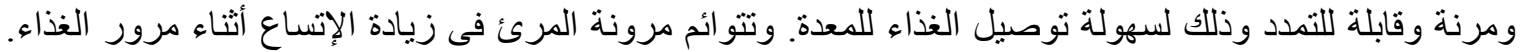

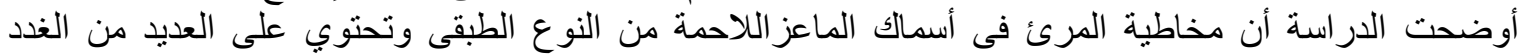

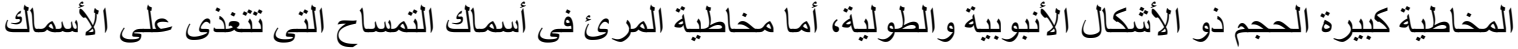

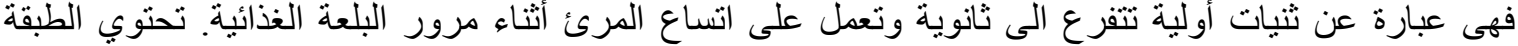

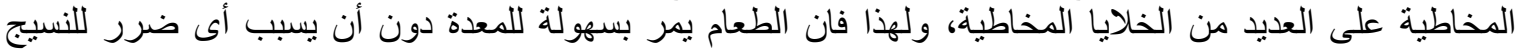

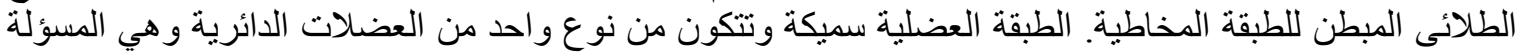

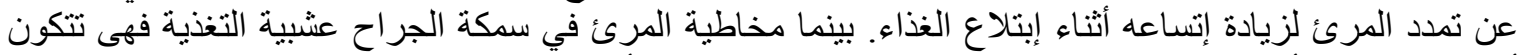
أيضا من ثنيات أولية تتفرع الى ثانوية وتعمل على اتساع المرئ أثناء مرور البلعة الغذائية وتتشابه في كثير من النو احى مع أسمالك التمساح. دل الوصف الظاهرى و النسيجى لمعدة الأسماك أن النوع و الثكل يختلف تبعا لنوع وطريقة التغذية، ففى التى الته

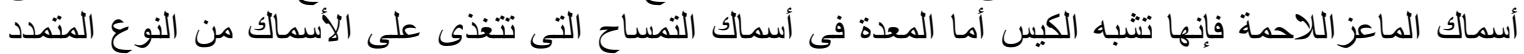

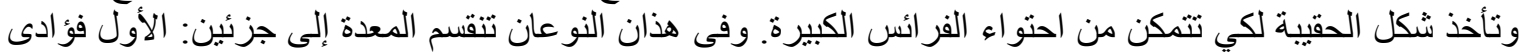

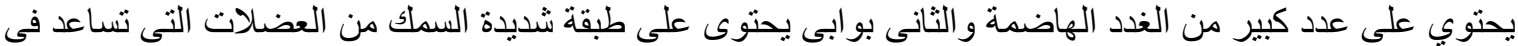

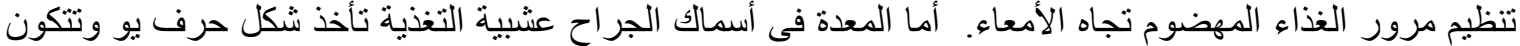

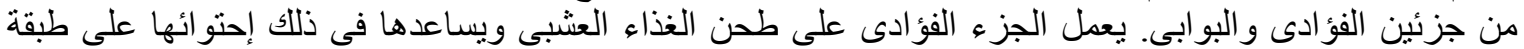

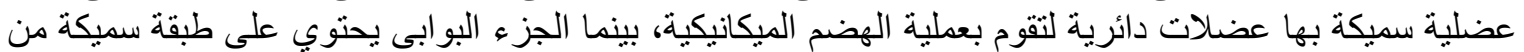

$$
\text { الغدد الهضمية لتقوم بالهضم الكيميائى. }
$$

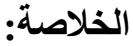

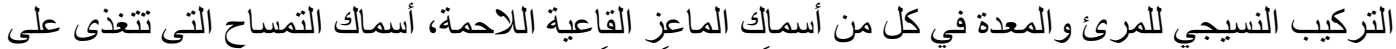

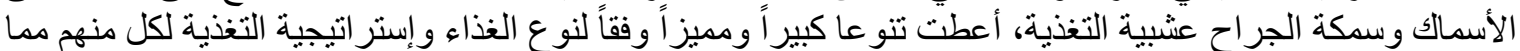

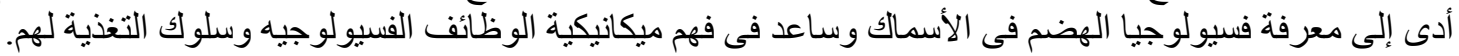

